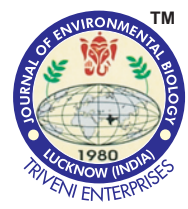

\title{
Macrobenthos community on the intertidal at Garolim Bay in summer
}

\section{Authors Info \\ S.H. Oh', J.H. Choi', D.S. Son ${ }^{2}$ and C.W. $\mathrm{Ma}^{2 *}$ \\ ${ }^{1}$ National Institute of Fisheries Science Fisheries Resources Research Center, Tongyeong, 53064, Korea ${ }^{2}$ Department of Life Science and Biotechnology, Soonchunhyang University, Asan, 31538, \\ South Korea}

*Corresponding Author Email : cwooma@sch.ac.kr

\section{Edited by}

Dr. Jong Chun Kim

\section{Reviewed by}

Dr. Hyeong Sum Han

Dr. Ki Won Lee

\section{Abstract}

Aim: The present study was performed to understand the macrobenthic community in 49 stations of intertidal at Garolim Bay during summer.

Methodology: The surface layer sediments and macrobenthos were collected by using the methods employed for the study conducted by Shin et al. (2004) to compare changes in the community of macrobenthos and components of the sediment in the intertidal at Garolim Bay. The improved model of Van Veen grab sampler of $0.045 \mathrm{~m}^{2}$ of its sampling area was used for sampling of surface layer sediments conducted on a ship in June 2015 at 49 stations placed in the intertidal at Garolim Bay.

Results: The sediment environment analysis revealed the mean ratio of sand at $55.50 \%$ followed by $41.72 \%$ silt and $2.78 \%$ clay, respectively. A total of 120 species of intertidal macrobenthos with a density of 630 individuals $\mathrm{m}^{-2}$ were investigated. The mean biomass thereof was $22.59 \mathrm{~g}$ wwt $\mathrm{m}^{-2}$. The most dominant species was polychaetes, Heteromastus filiformis (68.58\%), Mediomastus californiensis (9.43\%), crustaceans Ilyoplax pingi, crustaceans Macrophthalmus japonicus and so on. After analyzing the correlation coefficient between biotic in and sediment, the abundance and species evenness were found significantly related to environment factors.

Interpretation: In this study, six species of polychaete appeared on the top 10 dominant species; and among them, two species of $H$. filiformis and $M$. californiensis belonging to Capitellidae were found with $50 \%$ habitation density and more than $75 \%$ occupancy.

Key words: Community structure, Garolim Bay, Macrobenthos, Polychaeta

To know the community structure and temporal change of macrobanthos at Garolime Bay

Sedimentary environment
$\begin{aligned} & \text { - The average } 55 \% \text { of sand ratio contained in the collected } \\ & \text { sediment; were mainly consisted of silty sand or sandy } \\ & \text { silt }\end{aligned}$
$\begin{aligned} & \text { - Average grain size } \varnothing 0.51-\varnothing 5.58 \\ & \text { - Total } 120 \text { spacies, mean density; } 630 \text { individuals m-2 } \\ & \text { and mean biomass: } 22.6 \mathrm{~g} \text { wwtm-2 }\end{aligned}$
$\begin{aligned} & \text { The } 6 \text { species of polychaete appeared in the top } 10 \\ & \text { dominant species }\end{aligned}$
$\begin{aligned} & \text { - By comparing the facies investigated in summer } 2002 \\ & \text { with the facies investigated in summer } 2015, \text { the } \\ & \text { average grain size of sediment was found coarsened }\end{aligned}$

With the significantly lower level of species diversity and habitation density than those of other domestic back bays, and with the aspects of extreme dominance of the two species of Heteromastus filiformis and Mediomastus californiensis therein, the sedimentary environment of the intertidal at Garolim Bay was concluded that it has been disturbed by the contamination of organic materials for a long time and affects the distribution of annelids continuously.

How to cite: Oh, S.H., J.H. Choi, D.S. Son and C.W. Ma: Macrobenthos community on the intertidal at Garolim Bay in summer. J. Environ. Biol., 40, 896-907 (2019). DOI: http://doi.org/10.22438/jeb/40/5(SI)/SI-10 


\section{Introduction}

Tidal flat is one of important feature of coastal wetlands wherein materials are interchanging between open sea, coastal area and terrestrial ecosystems. Thereby, tidal flat is counted as an open ecosystem; it may carry characteristic communities varying according to local environment (Lee et al., 2001). The most important function of tidal flat among its several functions is purification of inflow of terrestrial contaminants (You and Kim, 1999). Macrobenthos, inhabiting tidal flat, occupy over $90 \%$ of entire species that inhabit whole marine ecosystem; they play important role as members of biodiversity (Thorson, 1957). Besides, they change nutrient salt in sediments through feeds of humic substance, mediate re-circulation of nutrient salt between sediments and sea water, and thereby occupy an important position in the ecosystem (Gray, 1974; Hartley, 1982). Thus, the number of species appearing, the density of habitation, and the structure of communities provide useful information for the assessing of structural stability and degree of health of sea area as well as degree of environmental disturbance (Parker, 1975; Rosenberg and Nilson, 2005; Wildsmith et al., 2009).

Garolim Bay is surrounded by the northern coast of Taean-gun County and Seosan-si of Chungcheongnam-do Province, extending $161.84 \mathrm{~km}$, the mouth is $3.2 \mathrm{~km}$ wide and the width of the meridian line of bay is $22.4 \mathrm{~km}$; this constitutes the semi-closed back bay of the shape of gourd bottle of narrow mouth and roomy inside. Due to topography, there are no big rivers near the bay; the inflow of fresh water to the bay thereby depends on small scaled tributaries. Inside the bay, the muddy flat takes its place whereas in the two water channels of the mouth of the bay and in the cuspidate foreland including islands thereof, the sedimentary facies of sands and gravels are distributed (MOF, 2007).

Several previous studies described the macrobenthos distribution pattern and inhabit in the Garolim Bay (Lee et al., 1983; Shin et al., 2004; Jung et al., 2014a), and Kim investigated the growth, mortality and production of Tapes philippinarum in Garolim Bay (Kim, 1986).

The present study was carried out to analyse spatial distribution of macrobenthos that inhabit the intertidal at Garolim Bay and sediments in order to understand the spatial utilization of benthic ecosystem; the effects of changes in sedimentary environment upon the community structure of macrobenthos will then identified to secure basic data and information for the analyses of macrobenthos communities that inhabit the Garolim Bay.

\section{Materials and Methods}

Collection of sediments and macrobenthos samples : The surface layer sediments and macrobenthos were collected by using the methods employed for the study conducted by Shin et al. (2004) to compare changes in the community of macrobenthos and components of the sediment in the intertidal at Garolim Bay. The improved model of Van Veen grab sampler of $0.045 \mathrm{~m}^{2}$ of its sampling area was used for the sampling of surface layer sediments conducted on a ship in June 2015 at 49 stations placed in the intertidal at Garolim Bay (Fig. 1). The collected samples were analyzed according to the procedural test standards of sediments (MOF, 2013) for which, the measurements of grain size, mean phi, total carbon, inorganic carbon, total organic carbon and total nitrogen were obtained.

Macrobenthos samples were also collected from same station of sediment sampling for which, the bottom sampler was used three times at each station to collect three samples at high tide; the collected samples were then filtered with $1 \mathrm{~mm}$ mesh screen and the remaining residues were fixed in $10 \%$ neutral formalin solution and transferred to laboratory.

Identification of macrobenthos: Macrobenthos samples were counted after identification up to the level of available species under dissecting microscope (Olympus-SZX12); and the wet weight was measured. Annelids were idebtified according to the classification system presented by Paik (1989) whereas identification of molluska, arthropod and echinoderm was carried out by employing the classification systems presented by Choe (1992), Kim (1972; 1990) and Shin and Rho (1996), respectively.

Community structure : For calculating the index of dominant species, the LeBris index, that takes the density of habitation and frequency of appearance of each species into account, was used.

$$
\begin{gathered}
D_{i i}^{\prime}=F_{i i} \times D_{i i} \times 100 \\
=\left\{\frac{P_{i j}}{P_{i}} \times 100\right\} \times\left\{\sum_{k=1}^{P_{i}} \frac{N_{i k}}{N_{k}}\right\} \times 100
\end{gathered}
$$

where, $P_{i j}$ is the frequency of appearance of the species $i$ in the $j^{\text {th }}$ community; $P_{i}$ is the number of entire station in the $j^{\text {th }}$ community; $N_{i k}$ is the density of habitation of the species i appeared at the $k^{\text {th }}$ station in the $j^{\text {th }}$ community and $N_{k}$ is the density of entire habitation at the $k^{\text {th }}$ station

Among the ecological indices, the index of species diversity (Shannon and Wiener, 1949), the index of species evenness (Pielou, 1966), and the index of species richness (Marglef, 1958) were calculated by using the program (Primer V 6.0, Primer-E Ltd.).

For calculating similarity between station, the common coefficient of Bray-Curtis similarity index (Bray and Curtis, 1957) was used; this was logarithmically converted to reduce the error in the density of habitation of dominant species from the calculation 


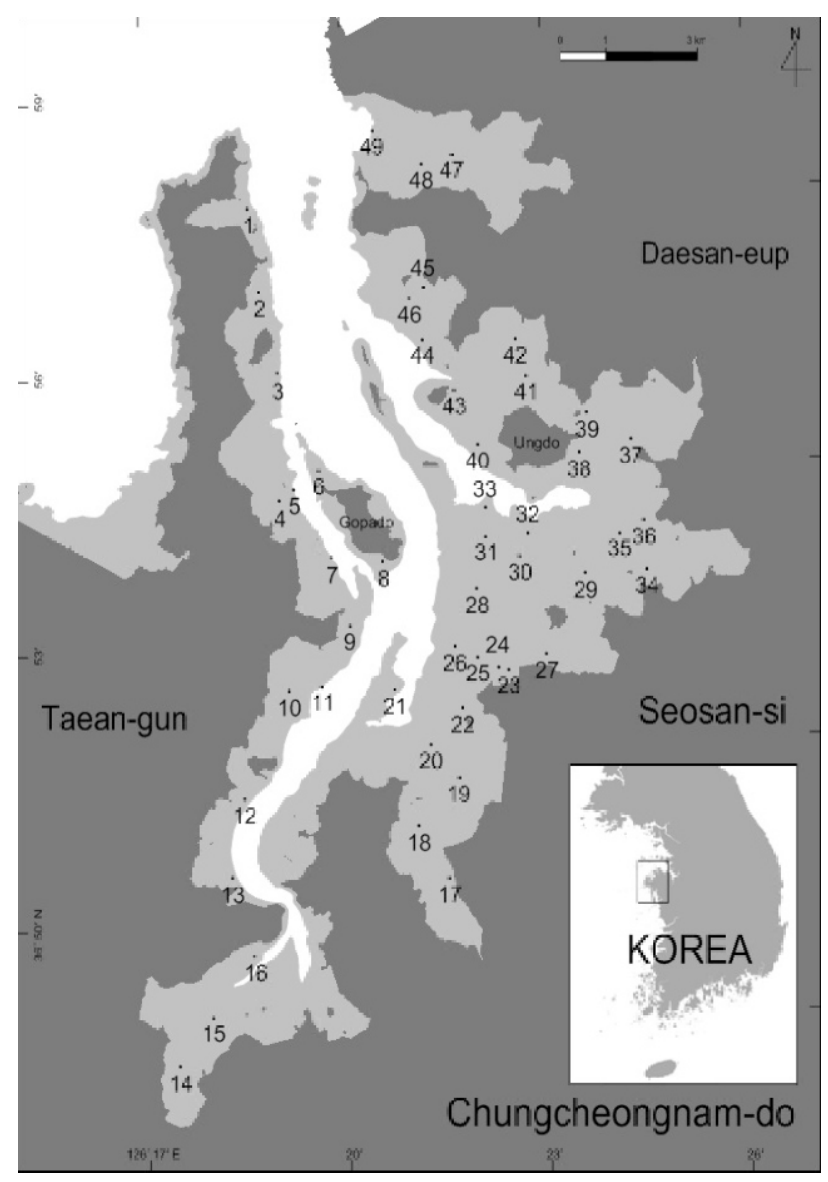

Fig. 1 : The sampling site of intertidal zone in Garolim Bay in 2015 summer.

employing the Primer V 6.0. The SIMPROF (Similarity Profile Analysis) Test was carried out together with the similarity analysis to distinguish groups from each other; the significance of each group was verified by Analysis of Similarities (ANOSIM). Similarity percentage procedure (SIMPER) Test was also carried out to identify the contribution of dominant species to demarcate groups at each station through Bray-Curtis Similarity Index; for calculating the difference in average values of habitation density between groups of each station, the data, converted into values of fourth root, were used.

Multivariate statistics package program (MVSP ver. 3.1) was used for canonical correspondence analysis (CCA) to identify the effects of components in sediment upon the community of macrobenthos. For Canonical Correspondence Analysis, top 10 dominant species, the composition and components of sediment were taken into account. Additionally, the correlation between the components of sediment, frequency of species, habitation density and dominant species, was analyzed by Spearman Rank Correlation Coefficient obtained from SPSS ver. 22 program.

\section{Results and Discussion}

Surface layer sediment: The surface layer sediment of intertidal at Garolim Bay was analyzed and the sand was found dominant with mean occupancy ratio of $55.50 \%$. The components of silt $(41.72 \%)$ and clay (2.78\%) were followed with respective mean grain sizes distributed in the range of $\varnothing 0.51-\varnothing 5.58$. The occupancy over $90 \%$ of sands were found from the station adjacent to Oji-risituated eastward from mouth of the bay and from those situated at both sides of the water channel; St. 6, St. 21, St. 44 , and St. 48. Among them, distribution of coarse-grained sands of respective mean grain sizes of $\varnothing 1.70$ and $\varnothing 0.51$ was found at St. 44 and St. 48. Overall, the sediments collected from Gopaisland westward from center of the bay, Woongdo island eastward from center of the bay, and the area neighboring the tidal flat of Seosan-si, were found with higher dominance of sands whereas sediments collected from the area distant from the water channel placed at the center of the bay were characterized by increasing dominance of silt (Fig. 2). The composition of total carbon, inorganic carbon, total organic carbon and total nitrogen in the sediments were $0.59 \%, 0.25 \%, 0.34 \%$ and $0.02 \%$, respectively. The inner- and central areas of the bay consisted high percent of total organic carbon and total nitrogen than those of other area. Inorganic carbon was found relatively at high concentration in some areas of the mouth and center of the bay (Fig. 3).

Macrobenthos community structure : The number of species, mean habitation density and mean value of biomass of the macrobenthos were 120,630 individuals $\mathrm{m}^{-2}$ and $22.59 \mathrm{~g} \mathrm{wwt} \mathrm{m}^{-2}$, respectively. Annelid were dominant $(43.3 \%)$ species and habitation density $(72.1 \%)$ whereas the mollusk occupied major position (51\%) in terms of biomass (Table 1).

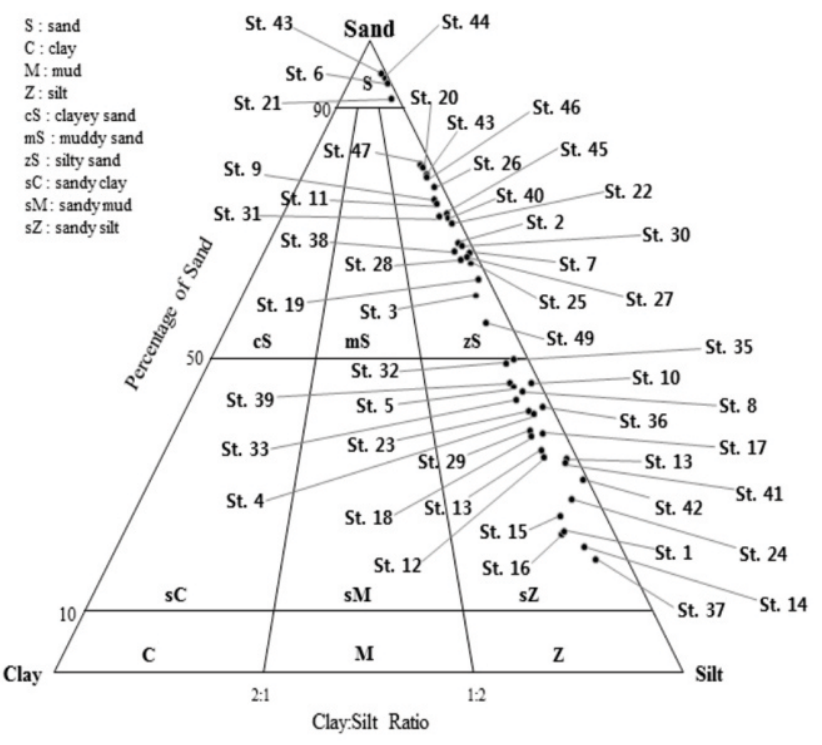

Fig. 2 : Diagram of surface sedimentary facies of Garolim Bay in 2015 summer. 


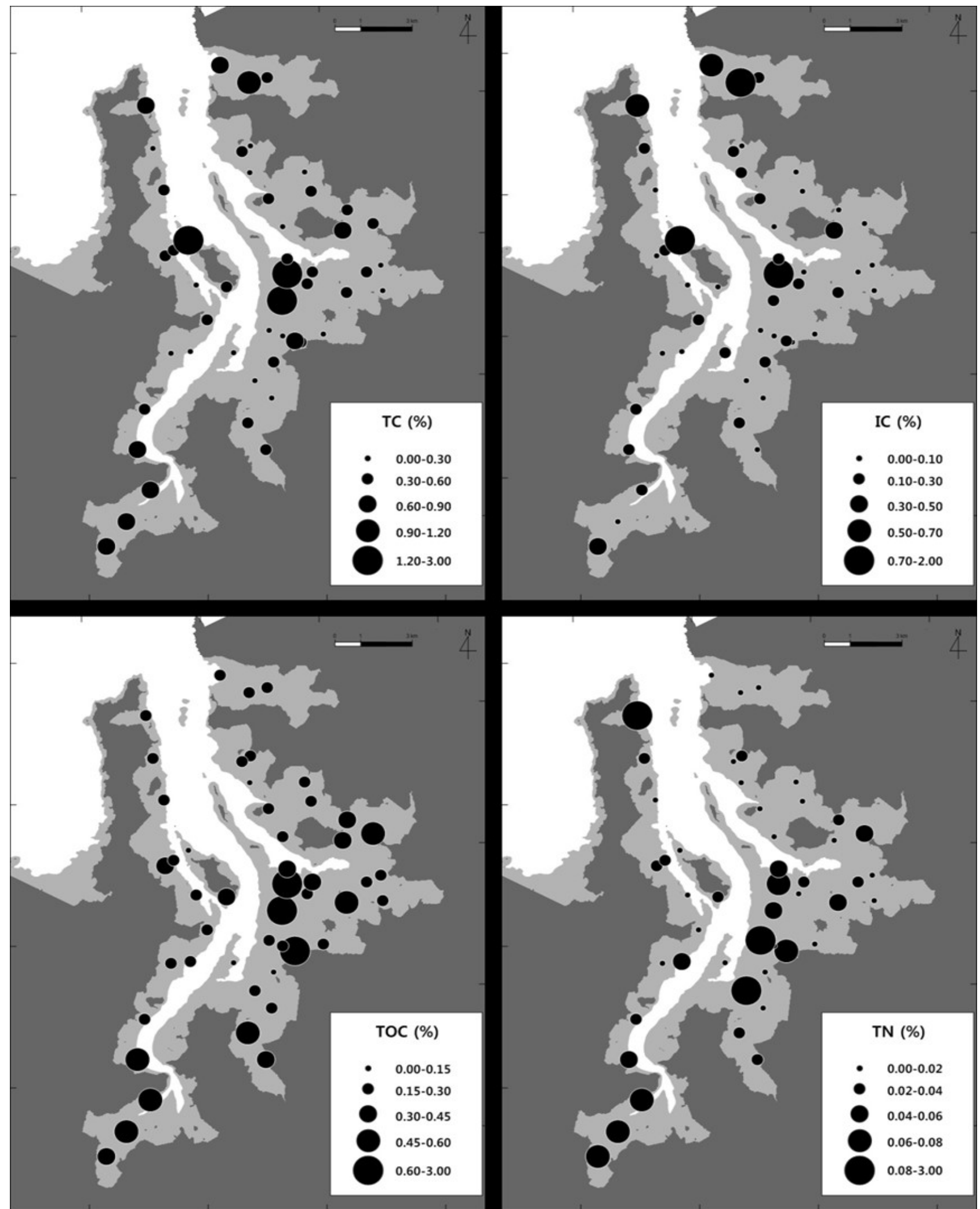

Fig. 3 : Ratio of total carbon (TC), inorganic carbon (IC), total organic carbon (TOC) and total nitrogen (TN) at each station of Garolim Bay in 2015 summer. 
In terms of number of species at each station, St. 31 of the tidal flat of Seosan-si placed in the center of the bay possessed largest number of species (23) whereas St. 16 situated near by Cheongsan-ri located southwestward from the bay possessed only one specie. The mouth and station near center of the bay were found with relatively more number of species; the number of species decreased towards mid of the bay. The habitation density of species was highest at St. 3 whereas lowest at St. 16. Highest values of habitation density was observed in the area westward from the bay (region of Taean-gun County), Woongdo island eastward from the bay, and tidal flat of Seosan-si whereas low habitation density was found in Cheongsan-ri placed southwestward from the bay, Ho-ri and Joongwang-ri located southward from the bay, and Hwanseong-ri placed eastward and deep inside the bay. The highest biomass was found at St. 31 marked whereas, at St.16 the lowest biomass of was observed (Fig. 4).

For the analysis of dominant species, habitation density and frequency of appearance were taken into account. The top ten dominant species occupied $95.7 \%$ of entire dominance. Among them, the most dominant species of Heteromastus filiformis occupied $65.58 \%$ of entire dominance with its habitation density of 300 indiv. $\mathrm{m}^{-2}$. The Mediomastus californiensis was found to be the second dominant species followed by llyoplax pingi, Macrophthalmus japonicus, Nephtys polybranchia, Aricidea spp., Nemertea unid., Ruditapes philippinarum, Lumbrineris japonica and Goniada japonica (Table 2). H. filiformis marked the largest density of 1,354 indiv. $\mathrm{m}^{-2}$ at St. 3 placed near the center of Taean peninsula westward from the bay. It appeared at all station with varied habitation densities. The next dominant species of $M$. californiensis appeared in 38 station that marked the second largest value of frequency of appearance. The top two dominant species commonly exhibited higher density of habitation at the area neighboring Gopa-island placed in the center of the bay. The frequency of appearance of other species was found half of the level of top two species with lower level of habitation density, except for certain places that marked specifically higher mean values of habitation density. Aricidea spp. and G. japonica were found from 21 stations and 20 stations, respectively, with lowest frequency of appearance whereas $I$. pingi was found with relatively higher habitation density in the area southwest of the bay and near by the tidal flat of Seosan-si. The mean value of habitation density of $R$. philippinarum was 21 indiv. $\mathrm{m}^{-2}$ belonged to higher rank of dominance, however, the mean values of habitation density at St. 2 and St. 4, located in the
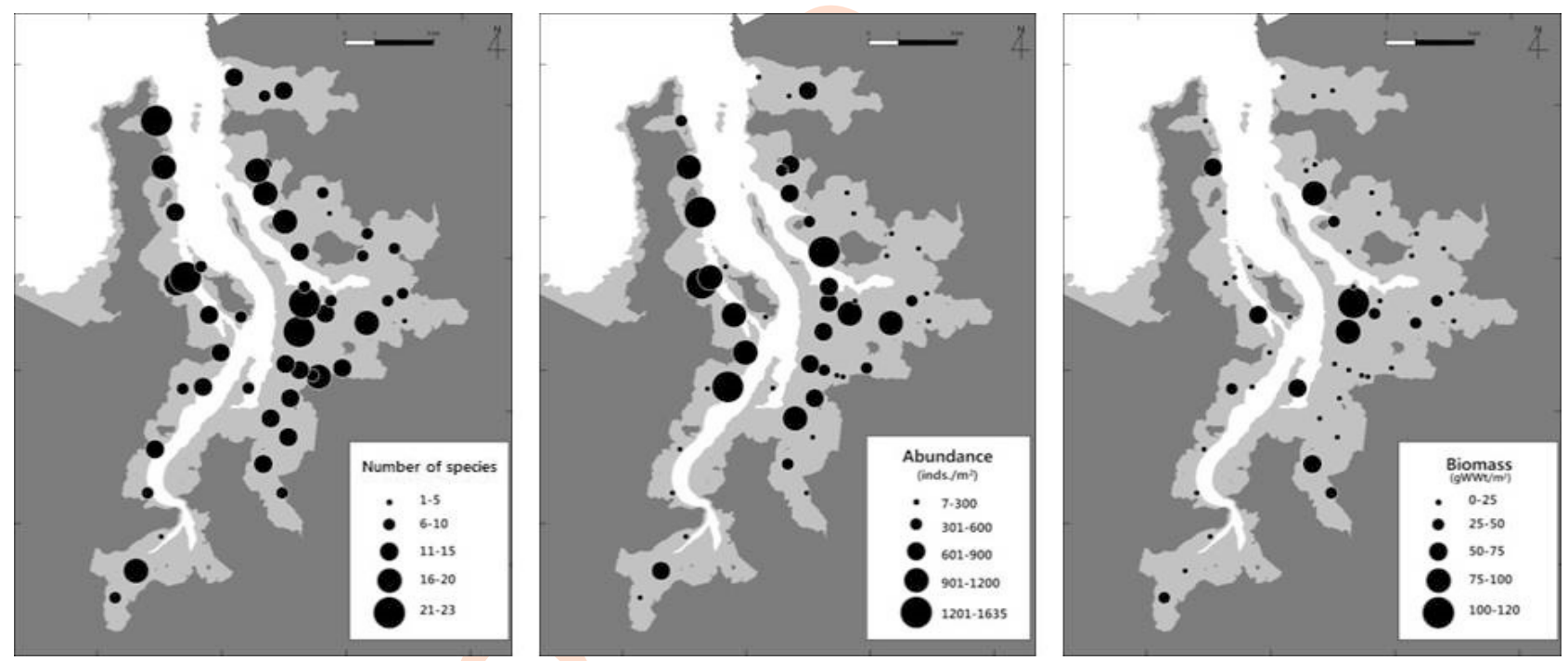

Fig. 4 : Number of species, abundance and density of macrobenthos at each station of Garolim Bay in 2015 summer.

Table 1 : Number of species, mean abundance and mean biomass at each group of macrobenthos of Garolim Bay in 2015 summer

\begin{tabular}{lllllll}
\hline Taxon & $\begin{array}{l}\text { Number of } \\
\text { species }\end{array}$ & $\%$ & $\begin{array}{l}\text { Mean abundance } \\
\text { (individuals } \mathbf{~ m}^{-2} \text { ) }\end{array}$ & $\%$ & $\begin{array}{l}\text { Mean biomass } \\
\left(\mathbf{g ~ w w t ~ m}^{-2} \text { ) }\right.\end{array}$ & $\%$ \\
\hline Annelida & 52 & 43.3 & 454 & 72.1 & 2.24 & 9.9 \\
Arthropoda & 32 & 26.7 & 83 & 13.2 & 7.80 & 34.5 \\
Mollusca & 31 & 25.8 & 80 & 12.7 & 11.63 & 51.5 \\
Others & 5 & 4.2 & 13 & 2.0 & 0.92 & 4.1 \\
Total & 120 & 100.0 & 630 & 100.0 & 22.59 & 100.0 \\
\hline
\end{tabular}


Table 2 : Dominant species by LeBris index of Garolim Bay in 2015 summer

\begin{tabular}{lllll}
\hline Species name & Taxon & Abundance (individuals $\mathbf{~ m}^{-2}$ ) & \multicolumn{2}{c}{ Lebris index } \\
\cline { 4 - 5 } & & & $\mathbf{( x \mathbf { 1 0 } ^ { 4 } )}$ & $\mathbf{( \% )}$ \\
\hline Heteromastus filiformis & $\mathrm{Po}$ & 300 & 39.78 & 65.58 \\
Mediomastus californiensis & $\mathrm{Po}$ & 54 & 5.72 & 9.43 \\
Ilyoplax pingi & $\mathrm{De}$ & 25 & 2.83 & 4.67 \\
Macrophthalmusjaponicus & $\mathrm{De}$ & 14 & 2.39 & 3.93 \\
Nephtys polybranchia & $\mathrm{Po}$ & 28 & 1.90 & 3.13 \\
Aricidea spp. & $\mathrm{Po}$ & 9 & 1.28 & 2.11 \\
Nemerteaunid. & $\mathrm{Ne}$ & 21 & 1.27 & 2.09 \\
Ruditapesphilippinarum & $\mathrm{Bi}$ & 14 & 1.21 & 1.99 \\
Lumbrinerisjaponica & $\mathrm{Po}$ & 12 & 0.90 & 1.48 \\
Goniadajaponica & $\mathrm{Po}$ & 487 & 0.78 & 1.29 \\
Total & & 58.06 & 95.7 \\
\hline
\end{tabular}

Taxon-Po: Polychaeta; De: Decapoda; Ne: Nemertea; Bi: Bivalvia
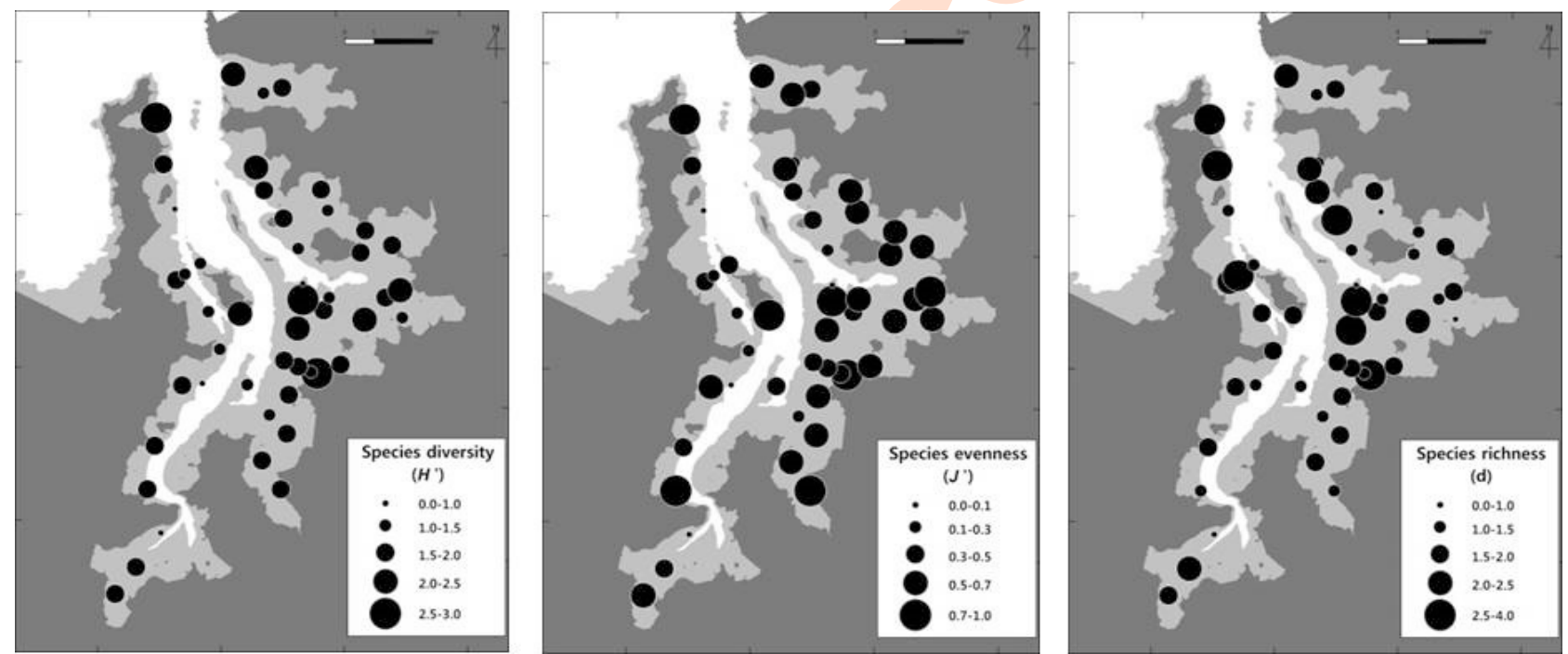

Fig. 5 : Ecological indices at each station of Garolim Bay in 2015 summer.

area of Taean-gun County, were 222 indiv. $\mathrm{m}^{-2}$ and 237 indiv. $\mathrm{m}^{-2}$, respectively, showing significant regional difference.

The mean value of indices of species diversity $(H)$, species evenness $(\mathrm{J})$ and species richness (d) were 1.615 (species diversity), 0.680 (species evenness) and 1.756 (species richness). The mouth of the bay, southward area from Gopaisland placed in the center of the bay, and the area neighboring tidal flat of Seosan-si exhibited relatively higher level of index of species diversity; St. 31 placed near the tidal flat of Seosan-si marked the largest value of 2.819. St. 36 of the tidal flat of Seosan-si placed in the center of the bay marked the largest value of species evenness (0.931) with in significant regional differences. The highest value of index of species richness (3.271) was found at St. 31 of tidal flat of Seosan-si placed in the center of the bay; on the whole, the index tend to have relatively lower values towards interior of the bay than those obtained from the mouth and center of the bay. St. 16, located near Cheongsanri, southwestward from the bay, marked the values of all indices 0 with the frequency of found species of only 1 (Fig. 5).

The results obtained from the Bray-Curtis Similarity Analysis and SIMPER test rendered the Group A of station scattered around the central water channel placed in the center of Garolim Bay whereas groups made of other station were distinguished into 10 distinct groups, wherein each group comprised 1-3 station. The similarity of station belonged to 'Group $A^{\prime}$ appeared $35.45 \%$ with 9 identified contributive species. $H$. filiformis contributed $31.44 \%$; succeeded by following species $M$. californiensis $(20.77 \%)$, M. japonicus $(8.32 \%)$, L. japonica 
(6.73\%), N. polybranchia (6.50\%), I. pingi (5.62\%), $R$. philippinarum (4.03\%), Nemertea unid. (3.38\%) and Aricidea spp. (3.25\%). In Group A, nine species among the top ten dominant species contributed to the formation of group of station. Group B which comprised of St. 48, located near the mouth of the bay with relatively high flow velocity, and St. 6 and St. 44, located near the water channel placed in the center of the bay, was found with the similarity of $36.375 \%$, wherein two species of $H$. filiformis $(29.42 \%)$ and $M$. californiensis $(23.15 \%)$ belonging to
Capitellidae, R. philippinarum (21.94\%), Glycera chirori (7.21\%), Typosyllis variegate $(7.08 \%)$ and Nematoda unid. (5.96\%) were identified as contributive species. $H$. filiformis and Aricidea spp. contributed to the formation of 'Group C' with the accumulated contributive effects over $80 \%$ that combined respective effects of $40.25 \%$ and $40.06 \%$; G. japonica occupied $7.85 \%$ of entire contributive effects. Station 16, 32 and 33 formed Group E; two stations located at the tidal flat of Seosan-si, St. 28 and St. 32 formed Group F, wherein 12 contributive species were identified.

Table 3 : Comparison of characteristic affinity groups by SIMPER test of Garolim Bay in 2015 summer

\begin{tabular}{|c|c|c|c|c|c|}
\hline & Species & Av. Abund & Av. Sim & Contrib\% & Cum.\% \\
\hline \multirow[t]{9}{*}{ GroupA } & Heteromastus filiformis & 4.22 & 13.00 & 31.44 & 31.44 \\
\hline & Mediomastus californiensis & 2.76 & 8.59 & 20.77 & 52.21 \\
\hline & Macrophthalmusjaponicus & 1.49 & 3.44 & 8.32 & 60.53 \\
\hline & Lumbrineris japonica & 1.49 & 2.78 & 6.73 & 67.26 \\
\hline & Nephtys polybranchia & 1.60 & 2.69 & 6.50 & 73.76 \\
\hline & Ilyoplax pingi & 1.32 & 2.32 & 5.62 & 79.38 \\
\hline & Ruditapes philippinarum & 1.16 & 1.67 & 4.03 & 83.41 \\
\hline & Nemertea unid. & 0.93 & 1.40 & 3.38 & 86.80 \\
\hline & Aricidea spp. & 0.94 & 1.35 & 3.25 & 90.05 \\
\hline \multirow[t]{6}{*}{ GroupB } & Heteromastus filiformis & 2.88 & 11.1 & 29.42 & 29.42 \\
\hline & Mediomastus californiensis & 2.10 & 8.73 & 23.15 & 52.56 \\
\hline & Ruditapes philippinarum & 1.98 & 8.28 & 21.94 & 74.50 \\
\hline & Glycera chirori & 1.38 & 2.72 & 7.21 & 81.71 \\
\hline & Typosyllis variegata & 1.44 & 2.66 & 7.05 & 88.75 \\
\hline & Nematoda unid. & 1.20 & 2.25 & 5.96 & 94.71 \\
\hline \multirow[t]{3}{*}{ GroupC } & Heteromastus filiformis & 2.88 & 15.52 & 44.25 & 44.25 \\
\hline & Aricidea spp. & 2.57 & 14.05 & 40.06 & 84.31 \\
\hline & Goniadajaponica & 1.20 & 2.75 & 7.85 & 92.15 \\
\hline \multirow[t]{4}{*}{ GroupD } & Ilyoplax pingi & 2.45 & 10.78 & 29.32 & 29.32 \\
\hline & Heteromastus filiformis & 1.74 & 10.19 & 27.71 & 57.03 \\
\hline & Nemertea unid. & 1.74 & 10.19 & 27.71 & 84.74 \\
\hline & Goniadajaponica & 1.20 & 2.80 & 7.63 & 92.37 \\
\hline \multirow[t]{3}{*}{ GroupE } & Heteromastus filiformis & 1.85 & 17.90 & 68.52 & 68.52 \\
\hline & Monocorophium sp. & 2.43 & 4.50 & 17.23 & 85.76 \\
\hline & Laternula marilina & 1.54 & 3.72 & 14.24 & 100.0 \\
\hline \multirow[t]{12}{*}{ GroupF } & Heteromastus filiformis & 4.00 & 6.79 & 11.48 & 11.48 \\
\hline & Mediomastus californiensis & 2.82 & 5.46 & 9.24 & 20.72 \\
\hline & Batillaria cumingii & 2.72 & 5.07 & 8.58 & 29.30 \\
\hline & Ruditapes philippinarum & 2.82 & 5.07 & 8.58 & 37.89 \\
\hline & Cirolanasp. & 2.52 & 4.86 & 8.22 & 46.11 \\
\hline & Patelloida conulus & 2.40 & 4.61 & 7.80 & 53.91 \\
\hline & Turbo coronata coreensis & 2.62 & 4.27 & 7.22 & 61.13 \\
\hline & Hemigrapsus penicillatus & 2.32 & 4.27 & 7.22 & 68.34 \\
\hline & Acmaea pallida & 2.41 & 3.88 & 6.56 & 74.90 \\
\hline & Lottia kogamogai & 2.27 & 3.88 & 6.56 & 81.46 \\
\hline & Abludomelita sp. & 2.07 & 3.88 & 6.56 & 88.02 \\
\hline & Nemertea unid. & 2.27 & 3.88 & 6.56 & 94.58 \\
\hline \multirow[t]{5}{*}{ GroupG } & Macrophthalmus japonicus & 2.34 & 13.14 & 26.45 & 26.45 \\
\hline & Heteromastus filiformis & 1.80 & 9.13 & 18.39 & 44.84 \\
\hline & Nephtys polybranchia & 1.80 & 9.13 & 18.39 & 63.23 \\
\hline & Hima fratercula hiradoensis & 1.80 & 9.13 & 18.39 & 81.61 \\
\hline & Dosinorbisjaponicus & 1.80 & 9.13 & 18.39 & 100.0 \\
\hline
\end{tabular}

Av. Abund:Average abundance;Av. Sim:Average similarity; Contrib \%: Contribute \%; Cum. \%: Cumulative \% 

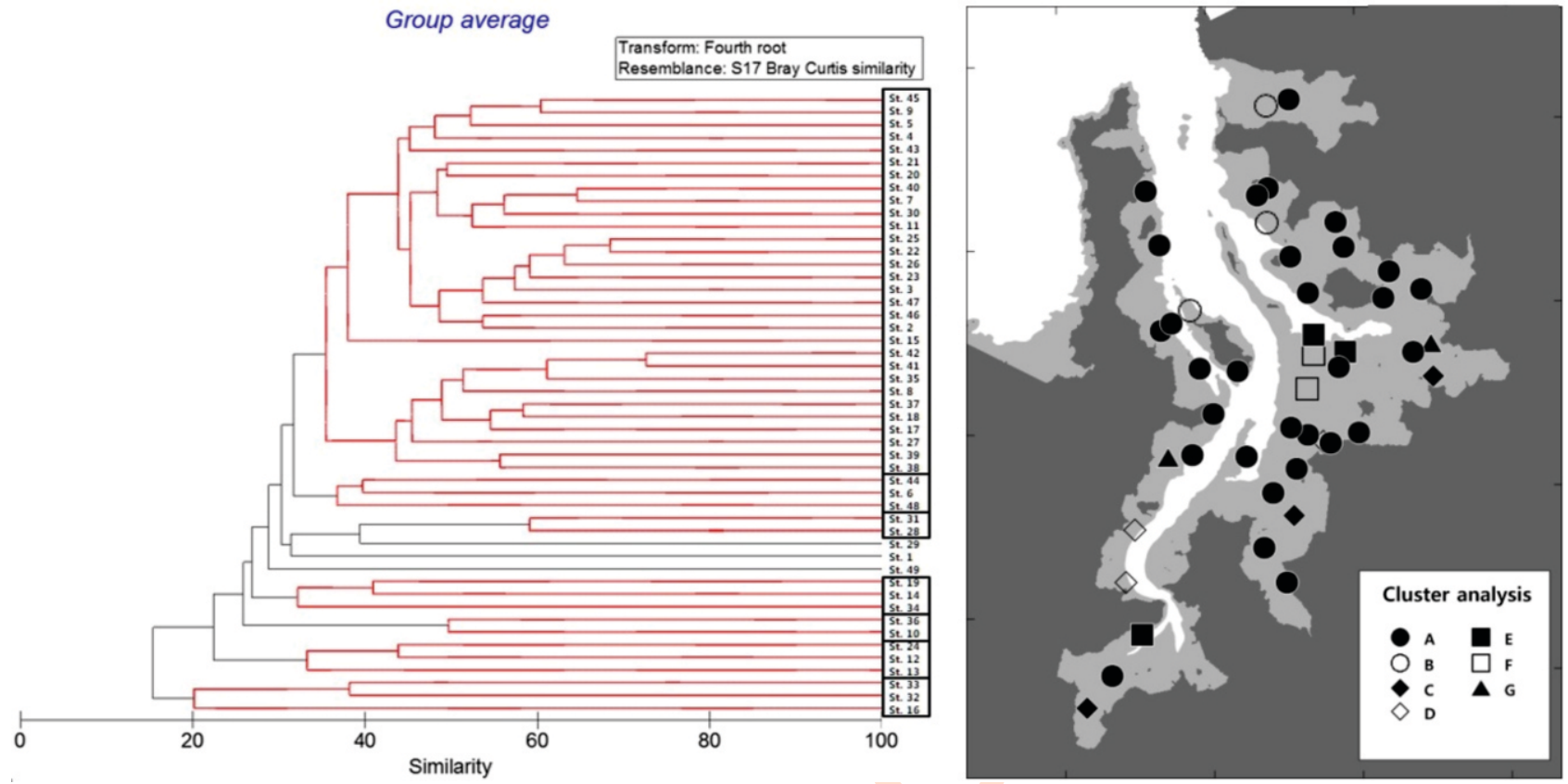

Fig. 6 : Dendrogram and distribution of each station group resulted from cluster analysis of Bray-Curtis similarity indices of macrobenthos of Garolim Bay in 2015 summer.

The similarity of Group E and Group F was $59.1 \%$ and $20.1 \%$, respectively (Table 3; Fig. 6).

The canonical correspondence of habitation density of top ten dominant species to components of sediment was analyzed. The top dominant species $H$. filiformis did not exhibit significant correlation whereas habitation density of $M$. californiensis and N. polybranchia showed negative correlation with the ratio of sands in the sediment. A positive correlation of habitation density of $I$. pingi and Nemertea unid. was found with the amount of clay and silt in sediment. The habitation density of $R$. philippinarum exhibited positive correlation with the amount of inorganic carbon whereas the habitation density of Nemertea unid. showed positive correlation with the amount of total carbon and organic carbon (Fig. 7, 8). Correlation between frequency of species appeared, top ten species of dominance, ecological indices (of species diversity, species richness, and species evenness), and the components of sediment was analyzed by obtaining the values of Spearman rank correlation coefficient. The results obtained from these analyses identified significant correlation between the components of sediment and the habitation density and index of species evenness. The habitation density of species exhibited negative correlation with respective coefficients of correlation $(r=-0.443, p<0.01$ and $r=-0.322$, $p<0.05$ ) with the ratio of silt in sediment and mean grain size whereas it also showed positive correlation with the ratio of sand in sediment, with correlation coefficient of $r=0.429, p<0.01$. On the contrary, the species evenness was found negatively correlated with the ratio of sand in sediment $(r=-0.322, p<0.05)$ while it was positively correlated with the ratio of silt in sediment $(r$ $=0.334, p<0.05)$ (Table 4). H. filiformis, M. californiensis, $N$. polybranchia, $R$. philippinarum and $L$. japonica commonly exhibited negative correlation with most of the components of sediment, except for the ratio of sand. Arthropods, I. pingi and G. japonica mostly manifested the correlation opposite to that of other dominant species (Table 5).

The sedimentary environment, to be physically influenced by sea water flow and tide, involves overall responses to the physico-chemical effects; the environment is thus referred to as the factors affecting the density of habitation and distribution of species of macrobenthos in previous studies delving into the community of macrobenthos (Wi, 2008; Warwick and Uncles, 1980; Snelgrove and Butman, 1994). Since Garolim Bay has few streams of freshwater, there is little inflow of terrestrial sediments, except for small scaled supply attributed to coastal erosion (Han, 1982). The sedimentary facies in the intertidal of Garolim Bay, investigated in summer 2002, showed higher ratio of sand in sediments collected from the mouth and center of the bay; the ratio of sand in sediment tend to decrease towards interior of the bay. The grain size was distributed in the quite broad range of $\varnothing$ $0.09-\varnothing 7.23$; as the general characteristics found from ordinary bays, the grain size tend to decrease as it went inward from the mouth of the bay (Shin et al., 2004). During the period from April 2006 to April 2007, the sedimentary facies of subtidal zone in the center at Garolim Bay mainly consisted of gravels and sands 


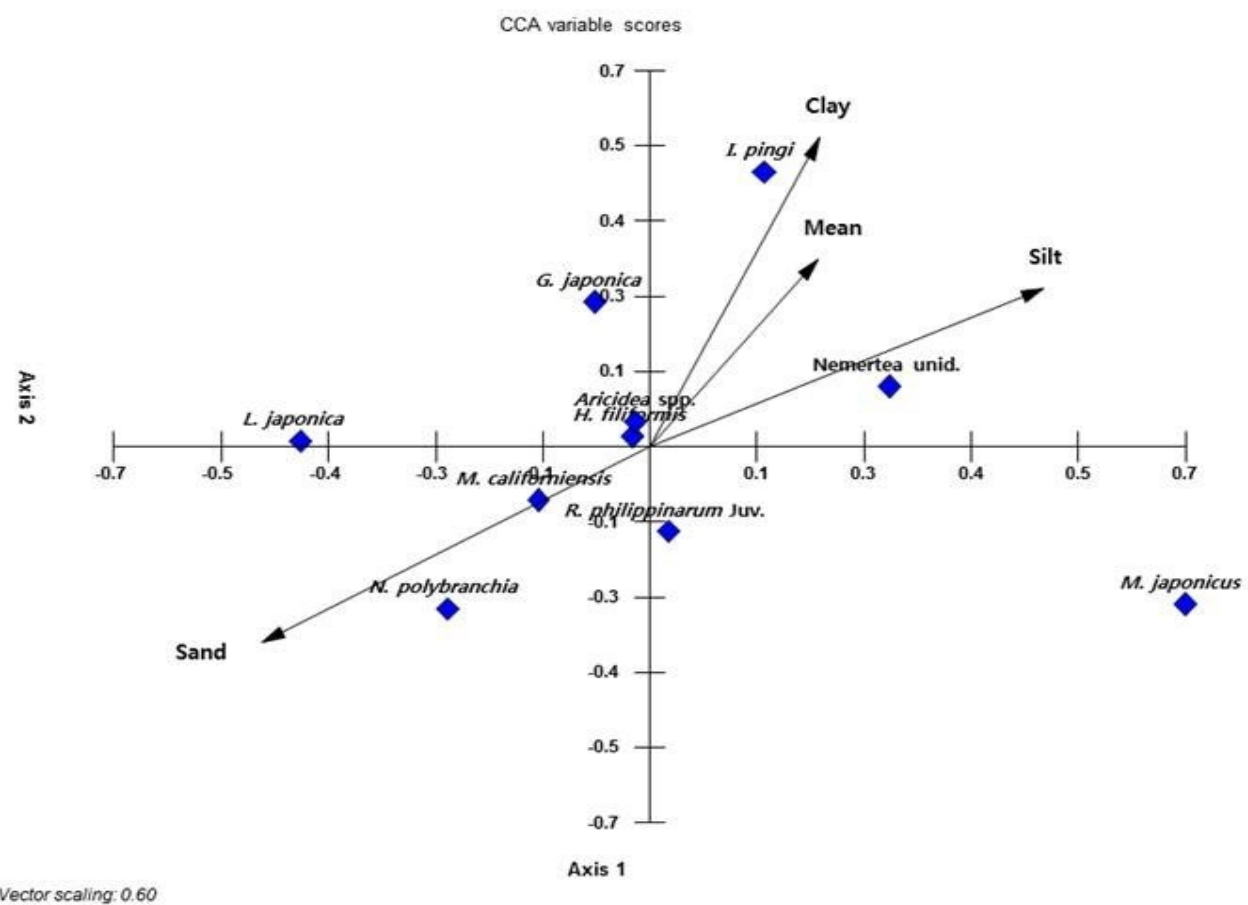

Fig. 7 : Canonical correspondence analysis (CCA) biplot between abundance of dominant species and sediment grain size of Garolim Bay in 2015 summer.

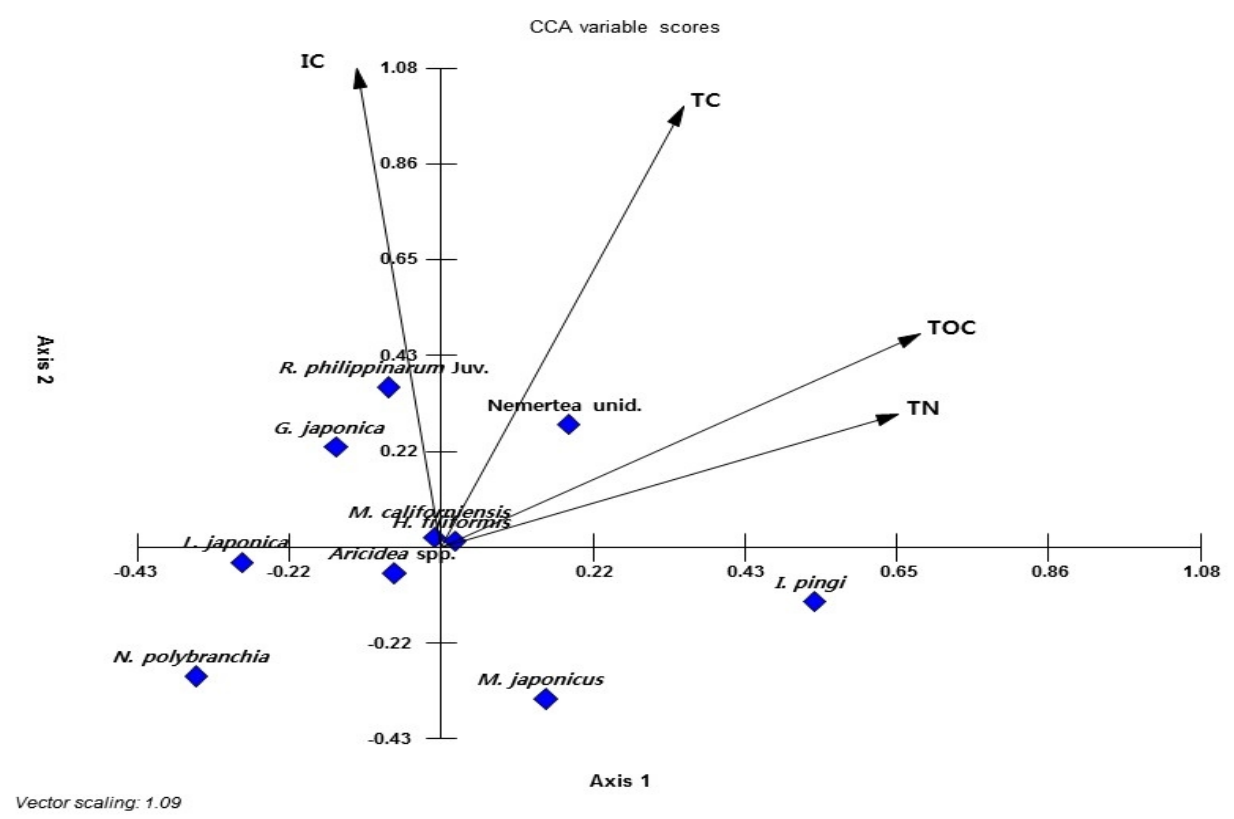

Fig. 8 : Canonical correspondence analysis (CCA) biplot between abundance of dominant species and environmental factors of Garolim Bay in 2015 summer.

while the area of Taean-gun County westward from the mouth of the bay, and the eastward and westward area from the center of the bay (the near by Cheongsan-ri of Taean-gun County), were mainly comprised of muddy facies, however, the facies manifested quite complex features wherein the specific weight of gravels and sands varied according to different places and seasons (Wi, 2008). The experiment conducted in this study showed average $55 \%$ of sand ratio contained in the collected 
Table 4 : Spearman rank correlation coefficient within the environmental, biological parameters and ecological indices of Garolim Bay in 2015 summer $\left({ }^{*}: p<0.05,{ }^{* *}: p<0.01\right)$

\begin{tabular}{llllll}
\hline & Species & Abundance & $\mathbf{H}^{\star}$ & J‘ & d \\
\hline TOC & -0.134 & -0.195 & 0.149 & 0.26 & -0.097 \\
TN & 0.038 & -0.02 & 0.074 & 0.061 & 0.039 \\
IC & 0.164 & 0.046 & 0.064 & 0.002 & 0.147 \\
Sand & 0.251 & $.429^{* *}$ & -0.144 & $-.322^{*}$ & 0.117 \\
Silt & -0.262 & $-.443^{* *}$ & 0.147 & $.334^{*}$ & -0.122 \\
Clay & -0.032 & -0.164 & 0.157 & 0.186 & 0.026 \\
Mean phi & -0.229 & $-.322^{*}$ & 0.022 & 0.161 & -0.132 \\
Mud & -0.251 & $-.429^{* *}$ & 0.144 & $.322^{*}$ & -0.117 \\
\hline
\end{tabular}

Table 5 : Spearman rank correlation coefficient within the environmental factors and LeBris index dominant species of Garolim Bay in 2015 summer $\left({ }^{*}: p<0.05,{ }^{* *}: p<0.01\right)$

\begin{tabular}{|c|c|c|c|c|c|}
\hline & $\begin{array}{l}\text { Heteromastus } \\
\text { filiformis }\end{array}$ & $\begin{array}{l}\text { Mediomastus } \\
\text { californiensis }\end{array}$ & Ilyoplax pingi & $\begin{array}{l}\text { Macrophthalmus } \\
\text { japonicus }\end{array}$ & $\begin{array}{l}\text { Nephtys } \\
\text { polybranchia }\end{array}$ \\
\hline TOC & $-.282^{\star}$ & -0.238 & $.357^{\star}$ & -0.056 & $-.508^{* *}$ \\
\hline TN & -0.174 & -0.203 & $.305^{*}$ & -0.057 & $-.393^{* *}$ \\
\hline IC & -0.114 & -0.081 & -0.097 & $-.414^{* *}$ & -0.164 \\
\hline Sand & $.484^{\star \star}$ & $.538^{\star \star}$ & -0.151 & -0.222 & $.389^{* \star}$ \\
\hline Silt & $-.491^{* *}$ & $-.542^{* *}$ & 0.13 & 0.253 & $-.366^{* *}$ \\
\hline Clay & $-.328^{*}$ & $-.339^{*}$ & $.298^{*}$ & -0.096 & $-.341^{*}$ \\
\hline Grain size & $-.411^{* *}$ & $-.503^{* *}$ & 0.223 & 0.023 & $-.327^{*}$ \\
\hline \multirow[t]{2}{*}{ Mud } & $-.484^{* *}$ & $-.538^{* *}$ & 0.151 & 0.222 & $-.389^{* *}$ \\
\hline & Aricidea spp. & Nemertea unid. & Ruditapes philippinarum & Lumbrineris japonica & Goniada japonica \\
\hline TOC & -0.147 & 0.046 & -0.082 & -0.276 & -0.155 \\
\hline TN & -0.076 & 0 & -0.064 & -0.162 & 0.061 \\
\hline IC & -0.075 & 0.078 & 0.204 & 0.065 & 0.249 \\
\hline Sand & 0.106 & -0.127 & $.290^{*}$ & $.419^{* *}$ & 0.048 \\
\hline Silt & -0.104 & 0.127 & $-.294^{*}$ & $-.423^{* *}$ & -0.06 \\
\hline Clay & -0.061 & 0.051 & -0.259 & -0.253 & 0.064 \\
\hline Grain size & -0.037 & 0.071 & $-.315^{\star}$ & $-.317^{\star}$ & -0.008 \\
\hline Mud & -0.106 & 0.127 & $-.290^{*}$ & $-.419^{\star *}$ & -0.048 \\
\hline
\end{tabular}

sediment; the sediments, sampled from most stations, mainly consisted of silty sand or sandy silt. The average grain size was distributed in the range $\varnothing 0.51-\varnothing 5.58$. The area of Taean-gun County westward from the mouth of the bay, and the innermost area of the bay (the near by Hwanseong-ri eastward from the bay, the near by Cheongsan-ri southwestward from the bay), appeared with the sediment of relatively fine grain size, however, as a whole the facies containing coarse-grained sand appeared dominantly. By comparing the facies investigated in summer 2002 with the facies investigated in summer 2015, the average grain size of sediment was found coarsened, however, the facies in the near by Cheongsan-ri southwestward from the bay showed increased portion of muddy sediment therein comparing to that in the facies investigated in summer 2002. This was estimated that it would be attributable to the regional slow flow velocity in the near by Cheongsan-ri and the absence of rivers/streams originated from the land that might have potentially facilitated the accumulation of muddy substance. The ratios of total organic carbon and total nitrogen in the surface layer sediment of intertidal at Garolim Bay appeared very low with average ratio of $0.34 \%$ and $0.02 \%$, respectively, except for the places in the near by Cheongsan-ri southwestward from the bay and in the area of tidal flat of Seosan-si eastward from the bay which were commonly distant from the water channel placed in the center of the bay showing relatively higher ratios thereof. As stated by Jung et al. (2014a), above results are the ones typically found from the environment wherein the coarse grained sediments including sands are dominant. The dominance of relatively coarse grained sediment is attributable to the fast flow velocity in the near by mouth and center of the bay; the tidal current facilitated thereby seem ascribable to the reduced accumulation of organic materials in sediment and decreased load of contamination. In 
Table 6 : Comparison of total number of species, mean abundance and mean biomass for the major taxonomic groups in 2002 summer (Shin et al., 2004) and 2015 summer

\begin{tabular}{|c|c|c|c|c|c|c|}
\hline \multirow{2}{*}{$\begin{array}{l}\text { Taxon } \\
\text { Year }\end{array}$} & \multicolumn{2}{|c|}{ Number of species } & \multicolumn{2}{|c|}{ Mean abundance (individuals $\mathrm{m}^{-2}$ ) } & \multicolumn{2}{|c|}{ Mean biomass $\left(\mathrm{g} \mathrm{wwt} \mathrm{m}^{-2}\right)$} \\
\hline & 2002 & 2015 & 2002 & 2015 & 2002 & 2015 \\
\hline Annelida & $64(43.5 \%)$ & $52(43.3 \%)$ & $791(69.4 \%)$ & $454(72.1 \%)$ & $3.8(2.4 \%)$ & $2.24(9.9 \%)$ \\
\hline Arthropoda & $35(23.8 \%)$ & $32(26.7 \%)$ & $100(8.8 \%)$ & $83(13.2 \%)$ & $20.9(13.3 \%)$ & $7.80(34.5 \%)$ \\
\hline Mollusca & $40(27.2 \%)$ & $31(25.8 \%)$ & $219(19.2 \%)$ & $80(12.7 \%)$ & $132.0(83.9 \%)$ & $11.63(51.5 \%)$ \\
\hline Others & $8(5.4 \%)$ & $5(4.2 \%)$ & $29(2.5 \%)$ & $13(2.0 \%)$ & $0.5(0.3 \%)$ & $0.92(4.1 \%)$ \\
\hline Total & 147 & 120 & 1,140 & 630 & 157.2 & 22.6 \\
\hline
\end{tabular}

summer 2015, the number of species, habitation density and mean biomass of macrobenthos inhabit the Garolim Bay were 120,630 indiv. $\mathrm{m}^{-2}$ and $22.6 \mathrm{~g}$ wwt $\mathrm{m}^{-2}$, respectively; the habitation density was comparatively lower than those of Ulsan Bay $(4,578$ indiv. $\mathrm{m}^{-2}$; Yoon et al., 2009), Jinhae Bay (1,939 indiv. $\mathrm{m}^{-2}$; Paik and Yun, 2000), Hampyeong Bay (1,168 indiv. $\mathrm{m}^{-2}$; Lim and Choi, 2001) and Cheonsu Bay (1,940 indiv. $\mathrm{m}^{-2}$; Jung et al., 2014b). In particular, the level of habitation density and biomass of macrobenthos appeared significantly lower than the results obtained from the study conducted by Shin et al. (2004) (Table 6). Crassostrea gigas, Batillaria cumingii and Umbonium moniliferum belong to genus Umbonium costatum etc., found from the investigation conducted in 2002, were not found from the investigation conducted in this study. However, in the case of $R$. philippinarum, the juveniles or spats of relatively smaller biomass were found dominant in some region (Shin et al., 2004). Such a highly frequent appearance of the juveniles or spats of $R$. philippinarum seems ascribable to the spats artificially spread over by some of sea farms. M. japonicus and I. pingi which are belonging to the family of arthropod have been known as representative crustaceans inhabit the south and west coasts of Korean peninsula (Koh and Shin, 1988; An and Koh, 1992). However, habitation of $M$. japonicus and $I$. pingi in the facies containing coarse grained sands was identified in this study. As some regions among entire area at Garolim Bay show complex forms of facies wherein the relatively fine grained silt and coarse grained sands are distributed closely, the habitation of two species seem attributable thereto.

Annelida is a biota of largest habitation density and highest frequency of species found among entire benthic organisms; this biota is quite important from ecological perspective (Fauchald and Jumars, 1979). In particular, most species belonging to Capitellidae are very tolerant to heavy metal and organic matter; they are the opportunistic species capable of rapidly propagating in the reduction zone; they are known as indicator species in the sea area contaminated by organic materials or in the disturbed benthic environment. They appear as dominant species in the coastal zone including tidal flat, in the back bay, and in the sea area wherein the fish farms are concentrated (Word, 1978; Grizzle, 1984; Weston, 1990; Horng and Taghon, 1999; Borja et al., 2000). Besides, they are also known to appear with higher density of habitation regardless of facies, of level of tidal water, or of effects of outer sea water (Jung et al., 2014b). In summer 2002, M. californiensis was found as the most dominant species in the intertidal at Garolim Bay; which was succeeded by the next dominant species of $H$. filiformis; the two species occupied more than $50 \%$ of entire habitation density thereof; they were commonly identified as species affecting the similarity at each station and formation of group of station (Shin et al., 2004). In this study, the six species of polychaete appeared in the top ten dominant species; and among them, the two species of $H$. filiformis and $M$. californiensis belonging to the Capitellidae were found with $50 \%$ habitation density and greater than $75 \%$ of occupancy therein. Besides, the total organic carbon, silt and clay were found negatively correlated with the average grain size; and positively correlated with sand. The correlation was identified through relatively higher frequency of appearance and habitation density of two species of $H$. filiformis and $M$. californiensis commonly found from the area employed in previous studies (Shin et al., 2004; Wi, 2008; Jung et al., 2014a). Seo and Hong previously suggested that two species should preferably be taken rather as opportunistic species to be classified into the ones of indicator species of contamination (Seo and Hong, 2004).

Consequently, with the significantly lower level of species diversity and habitation density than those of other domestic back bays, and with the aspects of extreme dominance of two species of $H$. filiformis and $M$. californiensis therein, the sedimentary environment of intertidal at Garolim Bay is contaminated by organic materials for a long time and affects the distribution of annelids.

\section{References}

An, S.M. and C.H. Koh: Environments and distribution of benthic animals on the Mangyungdongjin tidal flat, west coast of Korea. J. Oceano. Soc. Kor., 27, 78-90 (1992).

Borja, A., J. Franco and V. Perez: A marine biotic index to establish the ecological quality of soft-bottom benthos within European estuarine and coastal environments. Mar. Pol. Bull., 40, 1100-1114 (2000).

Bray, R.J. and J.T. Curtis: An ordination of the upland forest communities of Southern Wisconsin. Ecol. Monogr., 27, 325-349 (1957).

Choe, B.L.: Illustrated encyclopedia of fauna and flora of Korea. Vol. 33, 
Mollusca (2). 860 (1992).

Fauchald, K. and J. Jumars: The diet of worms: A study of polychaete feeding guilds. Oceanogr. Mar. Biol. Ann. Rev., 17, 193-284 (1979).

Gray, J.S.:Animal-sedimant relationship. Oceanogr. Mar. Biol. Ann. Rec., 12, 223-261 (1974).

Grizzle, R.E.: Pollution indicator species of macrobenthos in a coastal lagoon. Mar. Ecol. Prog. Ser., 18, 191-200 (1984).

Han, S.J.: The clay mineralogy of recent sediment in Garolim Bay, Korea. J. Geol. Soc. Kor., 18, 215-220 (1982).

Hartley, J.P.: Methods for monitoring off-shore macrobenthos. Mar. Pollut. Bull., 13, 150-154 (1982).

Horng, C.Y. and G.L. Taghon: Effects of contaminated sediments on particle size selection by the polychaete Capitella sp. I. J. Exp. Mar. Biol. Ecol., 242, 41-57 (1999).

Jung, R.H., I.S. Seo, W.C. Lee, H.C. Kim, J.B. Kim, B.M. Choi, J.S. Yun and J.H. Na: Community structure and health assessment of macrobenthic assemblages at spring and summer in Garorim Bay, west coast of Korea. J. Korean Soc. Mar. Environ. Saf., 20, 491503 (2014a).

Jung, R.H., I.S. Seo, W.C. Lee, H.C. Kim, S.R. Park, J.B. Kim, C.W. Oh and B.M. Choi: Community structure and health assessment of macrobenthic assemblages at spring and summer in Cheonsu Bay, west coast of Korea. J. Korean Soc. Oceano., 19, 272-286 (2014b).

Kim, H.S.: Illustrated encyclopedia of fauna and flora of Korea. Anomura and Brachyura. Vol. 14,694 (1972).

Kim, H.S.: Illustrated encyclopedia of fauna and flora of Korea. Vol. 19, Macrura. 414 (1990).

Koh, C.H. and H.C. Shin: Environmental characteristics and distribution of macrobenthos in a mudflat of the west coast of Korea (Yellow sea). Netherland J. Sea. Res., 22, 279-290 (1988).

Lee, J.H., J.S. Hong and S.K. Yi: Studies on the benthic fauna in Garolim Bay, Korea. Subtidal soft-bottom community. J. Korean Soc. Oceano., 18, 111-116 (1983).

Lee, J.J., K.C. Kang and J.C. Kim: Spatial species diversity of macrobenthos in the intertidal zone of Hwasoon, Jeju islands. Korean J. Malacol., 17, 63-70 (2001).

Lim, H.S. and J.W. Choi: Community structure of subtidal macrobenthos in Hampyung Bay during autumn in 1997, southwest coast of Korea. Korean J. Fish. Aquat. Sci., 34, 327-339 (2001).

Margalef, R.: Temporal succession and spatial heterogeneity in phytoplankton. In: Perspectives in Marine Biology. (Ed.: BuzzatiTraverso). Univ. Calif. Press. Berkeley, pp. 347 (1958).

MOF (Ministry of Oceans and Fisheries).: Assessment of Environmental Value of Garorim Gulf. MOF Final Report, pp.1-9 (2007).

MOF (Ministry of Oceans and Fisheries).: Korean Standard Methods for Marine Environment., pp. 516 (2013).
Paik, E.I.: Illustrated encyclopedia of fauna and flora of Korea. Vol. 31, Polychaeta. pp. 764 (1989).

Paik, S.G. and S.K. Yun: Community structure of the macrobenthos in Chinhae Bay. Korea. Korean J. Fish. Aquat. Sci., 33, 572-580 (2000).

Parker, R.H.: The study of benthic communities. A model and a review. Elsevier Scientific Publishing Company, pp. 277 (1975).

Pielou, E.C.: The measurement of diversity in different types of biological collections. J. Theoretical Biol., 13, 131-144 (1966).

Rosenberg, R. and H.C. Nilsson: Deterioration of soft-bottom benthos along the Swedish Skagerrak coast. J. Sea. Res., 54, 231-242 (2005).

Shannon, C.E. and W. Wiener: The mathematical theory of communication. Urbana. University of Illinois Press, pp. 1-177 (1949).

Seo, I.S. and J.S. Hong: The community ecology of benthic macrofauna on the Cheokjeon tidal flat, Incheon, Korea- 2. Spatio-temporal distribution patterns of the major dominant species. J. Korean Soc. Oceano., 9, 93-105 (2004).

Shin, S. and B.J. Rho: Illustrated encyclopedia of fauna and flora of Korea. Vol. 36, Echinodermata, pp. 780 (1996).

Shin, S.H., B.J. Gu and J.G. Je: Spatial distribution of benthic macrofauna on the tidal flat of Garolim Bay, West coast of Korea. J. Wetlands Res., 6, 57-72 (2004).

Snelgrove, P.V.R. and C.A. Butman: Animal sediment relationships revised: Cause versus effect. Oceanogr. Mar. Biol. Ann. Rev., 32, 111-177 (1994).

Thorson, G.: Bottom communities. Geol. Soc. Am. Mem., 67, 461-534 (1957).

Warwick, R.M. and R.J. Uncles: Distribution of benthic macrofauna associations in the Bristol Channel in relation to tidal stress. Mar. Ecol. Prog. Ser., 3, 97-103 (1980).

Weston, D.P.: Quantitative examination of macrobenthic community changes along an organic enrichment gradient. Mar. Ecol. Prog. Ser., 61, 233-244 (1990).

Wildsmith, M.D., T.H. Rose, I.C. Potter, R.W. Warwick, K.R. Clarke and F.J. Valesini: Changes in the benthic macro invertebrate fauna of a large microtidal estuary following extreme modifications aimed at reducing eutrophication. Mar. Pollut. Bull., 58, 1250-1262 (2009).

Word, J.Q.: The infaunal trophic index. In: Southern California Coastal Water Research Project, Annual Report, El Segundo, CA, pp. 1939 (1978).

Yoon, S.P., R.H. Jung, Y.J. Kim, S.G. Kim, M.K. Choi, W.C. Lee, H.T. Oh and S.J. Hong: Macrobenthic community structure along the environmental gradients of Ulsan Bay, Korea. J. Kor. Soc. Oceano., 14, 102-117 (2009).

You, S.J. and J.G. Kim: Evaluation on the purification capacity of pollutants in the tidal flat. J. Kor. Fish. Soc., 32, 409-415 (1999). 